\title{
Myeloid surface antigen abnormalities in myelodysplasia: relation to prognosis and modification by 13-cis retinoic acid
}

\author{
R E CLARK, S A SMITH, A JACOBS
}

From the Department of Haematology, University of Wales College of Medicine, Heath Park, Cardiff

SUMMARY The relation between prognosis and lineage specific surface antigen expression on peripheral blood granulocytes and monocytes was studied using monoclonal antibodies and flow cytometry in 37 patients with myelodysplastic syndromes (MDS). Abnormalities in antigen expression were summarised as a score, and cases were divided into low (few abnormalities) and high (many abnormalities) groups. Survival was significantly worse in the "high" group (logrank $\chi^{2}=5 \cdot 793$, $p=0.016$ ), this group having a median survival of 31 weeks, compared with more than 67 weeks in the "low" group. No correlations were found between the score and any of the following: peripheral blood platelet and granulocyte count; FAB subtype; bone marrow blast cells and sideroblast count, or erythroid and myeloid progenitor growth. Antigen expression was also studied in six further cases of MDS before and after six weeks of treatment with 13-cis retinoic acid (CRA), $20 \mathrm{mg}$ given orally, and a comparison was made with six untreated patients studied before and after a similar time interval. In the treated group $58 \%$ of initially abnormal measurements reverted to normal, compared with $24 \%$ in the untreated group. Five of the six treated patients showed a decrease in the score, whereas only two of the six improved in the untreated group. The data indicate that myeloid antigen expression is a useful indicator of prognosis in MDS, and that antigen expression may be affected by treatment.

The myelodysplastic syndromes (MDS) are a group of haemopoietic stem cell disorders with differing manifestations but a common tendency to evolve into acute non-lymphoid leukaemia. ${ }^{1}$ The FAB group proposed a classification of these syndromes based on morphological appearances, ${ }^{2}$ but it has been suggested that a biological classification of MDS, based on functional abnormalities, may be of greater value. ${ }^{3}$ Granulocyte function is abnormal in many of these patients, and granulocyte adhesion, superoxide generation, chemotaxis, phagocytosis and intracellular killing capacity are abnormal in $50 \% .^{4} \mathrm{We}$ have previously reported both decreased myeloidmacrophage antigen expression and increased expression of aberrant antigens in about $50 \%$ of patients with MDS at the time of presentation. ${ }^{5}$ We now report the relation between myeloid-macrophage surface antigen abnormalities and prognosis, and the changes in antigen expression induced by treatment.

13-cis retinoic acid (CRA) inhibits the development of papillomas induced by carcinogens in mice ${ }^{6}$ and the malignant transformation of cultured cell lines. ${ }^{7}$ Accepted for publication 22 January 1987
It stimulates differentiation of HL60 cells while suppressing proliferation, ${ }^{8}$ and induces the expression of myeloid specific surface antigens. ${ }^{9}$ It also inhibits the proliferation of both normal and leukaemic colony forming units-granulocyte-macrophage $(\mathrm{CFU}-\mathrm{GM})^{1011}$ and those of patients with MDS. ${ }^{12}$ Therapeutic studies of CRA in patients with MDS, however, have so far proved disappointing. A beneficial effect on blood counts and marrow morphology has been described in individual cases, ${ }^{1314}$ though whether continuous treatment with doses that are well tolerated changes overall patient survival is not yet clear. ${ }^{15} \mathrm{We}$ report the effect of therapeutic CRA on myeloid surface antigens.

\section{Patients and methods}

Forty three patients with MDS were studied (21 men and 22 women, with an age range of 29-86 years; mean 61.8). All fulfilled the diagnostic criteria of Bennett $e$ al $^{2}$ as modified by May et al, ${ }^{16}$ and included 14 patients with refractory anaemia, 10 with sideroblastic anaemia, nine with refractory anaemia with 
Table 1 Antigen expression on myelodysplastic peripheral blood granulocytes and monocytes before and after six weeks' treatment with 13-cis retinoic acid

\begin{tabular}{|c|c|c|c|c|c|c|c|c|c|c|c|}
\hline \multirow[b]{2}{*}{ Case code } & \multicolumn{5}{|c|}{ Granulocytes } & \multicolumn{5}{|c|}{ Monocytes } & \multirow{2}{*}{$\begin{array}{l}\text { Surface } \\
\text { antigen score }\end{array}$} \\
\hline & $82 \mathrm{HI}$ & $82 \mathrm{H6}$ & $F M C 11$ & $\mathrm{Mo2}$ & FMCI7 & $82 \mathrm{HI}$ & $82 \mathrm{H6}$ & $F M C 11$ & $\mathrm{Mo2}$ & FMC17 & \\
\hline $\begin{array}{l}\text { Treated cases: } \\
\text { CF }(0)^{*}\end{array}$ & $\begin{array}{l}51 \\
65\end{array}$ & $\begin{array}{l}79 \\
88\end{array}$ & $\begin{array}{l}77 \\
91\end{array}$ & $\begin{array}{l}7 \\
5\end{array}$ & $\begin{array}{l}34 \\
26\end{array}$ & $\begin{array}{r}12 \\
3\end{array}$ & $\begin{array}{r}12 \\
7\end{array}$ & $\begin{array}{r}15 \\
3\end{array}$ & $\begin{array}{r}6 \\
14\end{array}$ & $\begin{array}{l}38 \\
24\end{array}$ & $\begin{array}{l}40 \\
20\end{array}$ \\
\hline WS $(0.88)^{*}$ & $\begin{array}{l}78 \\
72\end{array}$ & $\begin{array}{l}90 \\
84\end{array}$ & $\begin{array}{l}87 \\
47\end{array}$ & $\begin{array}{l}7 \\
4\end{array}$ & $\begin{array}{l}50 \\
20\end{array}$ & $\begin{array}{r}24 \\
7\end{array}$ & $\begin{array}{l}19 \\
18\end{array}$ & $\begin{array}{l}35 \\
34\end{array}$ & $\begin{array}{l}55 \\
44\end{array}$ & $\begin{array}{l}62 \\
48\end{array}$ & $\begin{array}{l}40 \\
30\end{array}$ \\
\hline $\operatorname{EV}(0.82)^{*}$ & $\begin{array}{l}75 \\
81\end{array}$ & $\begin{array}{l}76 \\
88\end{array}$ & $\begin{array}{r}5 \\
29\end{array}$ & $\begin{array}{l}4 \\
6\end{array}$ & $\begin{array}{l}65 \\
25\end{array}$ & $\begin{array}{r}11 \\
9\end{array}$ & $\begin{array}{l}10 \\
12\end{array}$ & $\begin{array}{r}6 \\
10\end{array}$ & $\begin{array}{r}8 \\
13\end{array}$ & $\begin{array}{l}38 \\
56\end{array}$ & $\begin{array}{l}30 \\
40\end{array}$ \\
\hline AG & $\begin{array}{l}21 \\
61\end{array}$ & $\begin{array}{l}10 \\
65\end{array}$ & $\begin{array}{l}21 \\
77\end{array}$ & $\begin{array}{l}2 \\
8\end{array}$ & $\begin{array}{l}11 \\
41\end{array}$ & $\begin{array}{r}12 \\
7\end{array}$ & $\begin{array}{r}12 \\
9\end{array}$ & $\begin{array}{l}15 \\
10\end{array}$ & $\begin{array}{r}9 \\
19\end{array}$ & $\begin{array}{l}75 \\
42\end{array}$ & $\begin{array}{l}60 \\
10\end{array}$ \\
\hline IP & $\begin{array}{l}21 \\
12\end{array}$ & $\begin{array}{l}40 \\
57\end{array}$ & $\begin{array}{l}24 \\
29\end{array}$ & $\begin{array}{l}3 \\
6\end{array}$ & $\begin{array}{l}3 \\
5\end{array}$ & $\begin{array}{r}12 \\
7\end{array}$ & $\begin{array}{r}21 \\
9\end{array}$ & $\begin{array}{r}16 \\
7\end{array}$ & $\begin{array}{l}7 \\
9\end{array}$ & $\begin{array}{r}8 \\
52\end{array}$ & $\begin{array}{l}70 \\
30\end{array}$ \\
\hline MW & $\begin{array}{l}69 \\
63\end{array}$ & $\begin{array}{l}83 \\
51\end{array}$ & $\begin{array}{l}32 \\
30\end{array}$ & $\begin{array}{l}4 \\
5\end{array}$ & $\begin{array}{r}11 \\
5\end{array}$ & $\begin{array}{r}31 \\
6\end{array}$ & $\begin{array}{l}10 \\
10\end{array}$ & $\begin{array}{l}28 \\
28\end{array}$ & $\begin{array}{l}41 \\
46\end{array}$ & $\begin{array}{l}58 \\
47\end{array}$ & $\begin{array}{l}20 \\
10\end{array}$ \\
\hline $\begin{array}{l}\text { Untreated cases: } \\
\text { DDy }\end{array}$ & $\begin{array}{l}7 \\
3\end{array}$ & $\begin{array}{l}8 \\
9\end{array}$ & $\begin{array}{r}14 \\
8\end{array}$ & - & - & $\begin{array}{l}35 \\
67\end{array}$ & $\begin{array}{l}49 \\
70\end{array}$ & $\begin{array}{l}75 \\
63\end{array}$ & $\begin{array}{l}24 \\
34\end{array}$ & $\begin{array}{l}52 \\
59\end{array}$ & $\begin{array}{l}75 \\
75\end{array}$ \\
\hline $\mathrm{CN}$ & $\begin{array}{l}84 \\
92\end{array}$ & $\begin{array}{l}84 \\
92\end{array}$ & $\begin{array}{l}69 \\
86\end{array}$ & $\begin{array}{l}6 \\
2\end{array}$ & $\begin{array}{l}42 \\
54\end{array}$ & $\begin{array}{l}13 \\
27\end{array}$ & $\begin{array}{l}13 \\
12\end{array}$ & $\begin{array}{l}16 \\
45\end{array}$ & $\begin{array}{l}19 \\
40\end{array}$ & $\begin{array}{l}66 \\
47\end{array}$ & $\begin{array}{l}30 \\
40\end{array}$ \\
\hline BG & $\begin{array}{l}64 \\
44\end{array}$ & $\begin{array}{l}67 \\
77\end{array}$ & $\begin{array}{l}45 \\
64\end{array}$ & $\begin{array}{l}4 \\
7\end{array}$ & $\begin{array}{l}5 \\
3\end{array}$ & $\begin{array}{l}9 \\
6\end{array}$ & $\begin{array}{l}9 \\
6\end{array}$ & $\begin{array}{l}23 \\
15\end{array}$ & $\begin{array}{l}23 \\
15\end{array}$ & $\begin{array}{l}78 \\
55\end{array}$ & $\begin{array}{r}10 \\
0\end{array}$ \\
\hline TT & $\begin{array}{l}70 \\
68\end{array}$ & $\begin{array}{l}70 \\
60\end{array}$ & $\overline{77}$ & $\overline{7}$ & Z & $\begin{array}{r}2 \\
23\end{array}$ & $\begin{array}{r}8 \\
13\end{array}$ & $\begin{array}{l}26 \\
20\end{array}$ & $\begin{array}{l}46 \\
54\end{array}$ & $\begin{array}{l}76 \\
58\end{array}$ & $\begin{array}{r}0 \\
22\end{array}$ \\
\hline DMo & $\begin{array}{l}51 \\
12\end{array}$ & $\begin{array}{l}89 \\
25\end{array}$ & $\begin{array}{l}67 \\
24\end{array}$ & $\begin{array}{l}6 \\
4\end{array}$ & $\begin{array}{l}78 \\
54\end{array}$ & $\begin{array}{r}10 \\
5\end{array}$ & $\begin{array}{r}28 \\
5\end{array}$ & $\begin{array}{l}6 \\
4\end{array}$ & $\begin{array}{l}7 \\
3\end{array}$ & $\begin{array}{l}26 \\
13\end{array}$ & $\begin{array}{l}40 \\
60\end{array}$ \\
\hline SCou & $\begin{array}{l}86 \\
70\end{array}$ & $\begin{array}{l}81 \\
83\end{array}$ & $\begin{array}{l}65 \\
76\end{array}$ & $\begin{array}{l}4 \\
9\end{array}$ & $\begin{array}{l}24 \\
26\end{array}$ & $\begin{array}{r}12 \\
6\end{array}$ & $\begin{array}{r}12 \\
5\end{array}$ & $\begin{array}{l}24 \\
13\end{array}$ & $\begin{array}{l}24 \\
32\end{array}$ & $\begin{array}{l}56 \\
47\end{array}$ & $\begin{array}{l}30 \\
10\end{array}$ \\
\hline Normal range & $43-93$ & $50-97$ & $47-85$ & $2-11$ & $2-11$ & $2-11$ & $1-11$ & $3-28$ & $14-71$ & $34-77$ & \\
\hline
\end{tabular}

*Plasma CRA concentration ( $\mu \mathrm{mol} / \mathrm{l})$ taken one to two hours after an alleged $20 \mathrm{mg}$ dose.

excess blasts (RAEB), three with RAEB in transformation, three with chronic myelomonocytic leukaemia, and four with idiopathic macrocytosis. Two patients only received low dose ara-C six and 16 months before the study.

\section{MYELOID ANTIGENS}

The expression of granulocyte specific and monocyte specific antigens was studied on both granulocytes and monocytes in peripheral blood using monoclonal antibodies. The granulocyte specific monoclonal antibodies used were $82 \mathrm{HI}$ and $82 \mathrm{H}^{17}$ and $\mathrm{FMCl} 1{ }^{18}$ $82 \mathrm{H} 1$ and $82 \mathrm{H} 6$ are CD15 monoclonal antibodies and recognise the $\mathrm{X}$ hapten. ${ }^{1920}$ FMC11 recognises an antigen expressed on metamyelocytes onward ${ }^{18}$ but has not been defined specifically. The monocyte specific monoclonal antibodies used were FMC17 and Mo2, which belong to the CDw14 cluster. ${ }^{21}$

Granulocytes and monocytes were separated from peripheral blood, and antibody binding was measured on each cell type by indirect immunofluorescence, as previously described. ${ }^{5}$ Stained cell suspensions were analysed in a FACS III cell sorter (Becton Dickinson) using a 4 watt argon ion laser at $488 \mathrm{nM}$. In a few cases samples were inadequate for study. The resulting fluorescence histograms were analysed using an Apple II EC Europlus microcomputer and homemade software, which calculated the percentage of positive cells for each sample by comparing each test histogram with a control histogram, as previously described. ${ }^{5}$

The normal range of antigen expression of granulocytes and monocytes was determined from 16 age matched volunteers who were either healthy laboratory staff or patients about to undergo minor eye surgery but who were otherwise healthy and not taking drugs. There were nine men and seven women with an age range of $25-84$ years (mean $61 \cdot 5) .{ }^{5}$ Table 1 shows the range of normal expression of each monoclonal antibody.

\section{EFFECT ON PROGNOSIS}

For each of the 37 cases on whom sufficient data were available, the degree of abnormality of surface antigen expression was summarised as a surface antigen score. This was defined as:

$$
\frac{\text { number of abnormal measurements }}{\text { total number of measurements }} \times 100
$$


Table 2 Prognostic relevance of low and high surface antigen scores

\begin{tabular}{lllcr}
\hline Surface antigen score & No of cases & No of deaths & $\begin{array}{l}\text { No of leukaemic } \\
\text { transformations }\end{array}$ & $\begin{array}{l}\text { Mean } \\
\text { survival (weeks) }\end{array}$ \\
\hline sow $(<30)$ & 20 & 8 & 1 & 111 \\
High $(>30)$ & 17 & 12 & 79 & 65 \\
Total & 37 & 20 & 8 & 16 \\
\hline
\end{tabular}

and is a measure of the proportion of abnormally expressed antigens. Abnormal expression was defined if the calculated percentage positivity fell outside the normal range (table 1$){ }^{5}$ Because up to five measurements were made on both granulocytes and monocytes, the denominator of the surface antigen score varied from 6-10 (no case had less than six measurements). All cases were followed up from the time of investigation until death, or for between 65 and 148 weeks.

\section{ADDITIONAL INVESTIGATION}

In each case peripheral blood counts were carried out by standard techniques and Jenner-Giemsa stained marrow film were examined, at least $\mathbf{4 0 0}$ marrow cells being counted in each case. Dyserythropoiesis was defined as a specific nuclear abnormality such as a megaloblastic appearance, binucleation, the presence of nuclear budding or Howell-Jolly bodies, or gaps in the nuclear membrane. On day 7 numbers of colony forming units-erythroid (CFU-E) were assayed by a modification of the method of Iscove et $a^{22}$ and CFU-GM colony numbers on day 7 by the method of Bailey-Wood et al. ${ }^{23}$ The Spearman rank correlation coefficient between these measurements and the surface antigen scores were calculated using the Biomedical Computer Programs P-series (BMDP) package. ${ }^{24}$ The relation between the FAB subtype and the surface antigen score was analysed by the KruskalWallis one way analysis of variance by ranks.

\section{EFFECT OF CRA}

In six cases antigen expression was studied before and after six weeks' treatment with CRA in a dose of $20 \mathrm{mg}$ given orally each day. None of these cases was included in the analysis of the effect of surface antigen scores on prognosis because CRA may have influenced their survival time. Six similar but untreated cases were also studied before and after an interval of six weeks. In three of the treated cases serum CRA titres were assayed by $\operatorname{Dr} G$ Allen of Roche Laboratories, using the method of McLean et $a l^{25}$ Some of the cases treated with CRA had minor mucocutaneous or conjunctival side effects. No change in liver function test results or triglyceride concentrations was observed.

\section{Results}

PROGNOSTIC RELEVANCE OF SURFACE ANTIGEN SCORE

The median value of the score (SAS) in the 37 cases for whom sufficient data were available was $30 \%$. Cases were divided into a low $(<30 \%)$ and a high $(>30 \%)$ group, and table 2 shows the proportion of deaths and leukaemic transformations in each group. The difference in the rate of leukaemic transformations between the two groups was highly significant $(p=0.014$, Fisher's exact test). Table 2 also shows the mean survival times at 65-148 weeks and the $75 \%$ survival times for each group. The median survival was 31 weeks in the high scoring group, but was not reached at 67 weeks in the low scoring group. The figure shows Kaplan-Meier survival curves for each group and the significant difference in survival (logrank $\chi^{2}=5.793, p=0.016$ )

\section{RELATION BETWEEN SURFACE ANTIGEN SCORE} AND OTHER PERIPHERAL BLOOD AND BONE MARROW ABNORMALITIES

No correlation was found between the score and peripheral blood platelet or granulocyte count, FAB subtype, bone marrow blast cells, sideroblast count or erythroid and myeloid progenitor growths. A weak negative correlation was observed with the peripheral blood haemoglobin $(r s=-0.44, p=0.006)$.

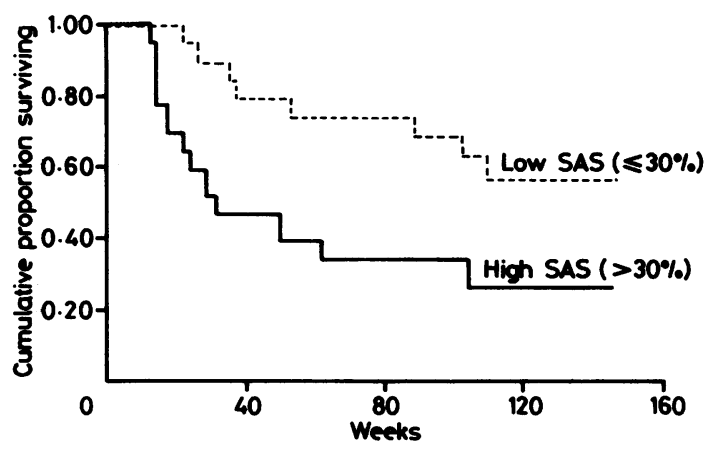

Figure Kaplan-Meier survival curves for groups with high and low' surface antigen scores. 


\section{EFFECT OF CKA}

The effect of CRA on granulocyte and monocyte specific antigen expression by granulocytes and monocytes in peripheral blood is shown in table 1 . In the treated group 15 of the 26 measurements abnormal initially $(58 \%)$ reverted to normal, compared with only four of $17(24 \%)$ in the untreated group. In the treated group $5 \%$ of measurements became abnormal during the study, compared with $11 \%$ in the untreated group. Five of the six treated cases showed an improvement in the surface antigen score, while only two of the six untreated cases improved; a further case remained abnormal (DDy). In two of the three patients in whom serum CRA concentrations. were measured those achieved were about $1 \mu \mathrm{mol} / \mathrm{l}$; in: the third patient no CRA was detected, suggesting non-compliance.

\section{Discussion}

Peripheral blood granulocytes and macrophages in MDS may exhibit not only decreased expression of appropriate antigens, but also increased expression of inappropriate ones. ${ }^{5}$ Hokland et al ${ }^{26}$ showed increased bone marrow mononuclear cell expression of $\mathrm{My} 7$ in some cases; this monoclonal antibody detects a CDw13 antigen. ${ }^{21}$ Such patients tended to evolve to acute myeloid leukaemia more rapidly and have shorter survival. The present data show that abnormal surface antigen expression, summarised as a score, is associated with poor survival in MDS. Those patients with high scores tended to survive less than one year, whereas those with low scores usually survived longer than 18 months (figure).

Surface membrane glycoproteins are important in phagocytic cell function. ${ }^{27}$ Membrane glycoproteins are important in mediating neutrophil adhesion ${ }^{28}$ and macrophage migration. ${ }^{29}$ Moreover, the stimuli which normally activate production of oxygen radicals in phagocytes depend on glycoprotein membrane receptors. ${ }^{30}$ The defective surface membrane glycoprotein expression of myelodysplastic phagocytes shown here may represent a more general glycoprotein deficiency on these cells, leading to less efficient phagocytosis, increased susceptibility to serious infection, and decreased survival. Further work is required to relate abnormal phagocyte function to surface antigen expression.

Those cases with a high score may have progressed further along the premalignant pathway, and so tend to have a shorter survival. There is little correlation, however, between the score and other prognostic variables such as the bone marrow blast number and peripheral blood cytopenia, both of which tend to change adversely during the evolution of the disease. Though a weak correlation is seen with peripheral blood haemoglobin concentration, this is difficult to interpret as some patients depend on transfusions. Surface antigen expression seems to be an independent prognostic variable.

The surface antigen score is closely related to subsequent leukaemic transformation. This is independent of the association with short survival, as many patients died in the absence of leukaemic transformation (table 2), often the case in this condition. ${ }^{31}$ The present association of high score and subsequent leukaemic transformation confirms the observations of Hokland et al, ${ }^{26}$ who showed that cases with abnormal bone marrow mononuclear cell $\mathrm{My} 7$ expression had an increased tendency to evolve to RAEB and acute myeloid leukaemia.

CRA has been shown to induce changes in antigen expression ${ }^{932}$ and surface glycoproteins on HL60 cells. ${ }^{33}$ Increases in antigens associated with maturing myeloid cells have been shown on acute nonlymphoid leukaemia blasts in vitro. ${ }^{34}$ The present data show improvement in abnormal surface antigen expression on peripheral granulocytes and monocytes from some myelodysplastic patients treated with CRA. Serum concentration in patients treated with $20 \mathrm{mg}$ CRA orally daily are about $1 \mu \mathrm{mol} / 1 .{ }^{15}$ At this concentration both differentiation promoting and antiproliferative effects may be shown in vitro in normal CFU-GM ${ }^{1035}$ and some leukaemic blasts, ${ }^{1136}$ and an antiproliferative effect has been shown on CFU-GM in MDS. ${ }^{12}$ The effect of CRA on surface antigen expression shown here may be mediated by inducing differentiation of normal progenitors, decreasing proliferation of abnormal progenitors, or a combination of these effects.

\section{References}

1 Jacobs A. Myelodysplastic syndromes: pathogenesis, functional abnormalities and clinical implications. $J$ Clin Pathol 1985;38:1201-17.

2 Bennett JM, Catovsky D, Daniel MT, et al. The FrenchAmerican-British (FAB) Cooperative Group. Proposals for the classification of the myelodysplastic syndromes. $\mathrm{Br} \mathrm{J} \mathrm{Haematol}$ 1982;51:189-99.

3 Greenberg PL, Bagby G. Biological rather than morphological markers in the myelodysplastic syndromes. $\mathrm{Br} \mathrm{J} \mathrm{Haematol}$ 1983;53:532-4.

4 Martin S, Baldock SC, Ghoneim ATM, Child JA. Defective neutrophil function and microbicidal mechanisms in the myelodysplastic disorders. J Clin Pathol 1983;36:1120-8.

5 Clark RE, Hoy TG, Jacobs A. Granulocyte and monocyte surface membrane markers in the myelodysplastic syndromes. J Clin Pathol 1985;38:301-4.

6 Bollag W. Therapy of chemically induced skin tumours of mice with vitamin A palmitate and vitamin A acid. Experientia 1971;27:90-2.

7 Bollag W. From vitamin A to retinoids; chemical and pharmacological aspects. In: Orfanos CE, ed. Retinoids; advances in basic research and therapy. Berlin: Springer-Verlag, 1981:5-12.

8 Olsson I, Breitman TR, Keene BR. Mechanisms for induction of 
differentiation in human myeloid leukaemic cell lines (HL60 + U937). Exp Hematol 1981;9 (suppl 9):41.

9 Perussia B, Lebman D, Ip SH, Rovera G, Trinchieri G. Terminal differentiation surface antigens of myelomonocytic cells are expressed in human promyelocytic leukaemia cells (HL60) treated with chemical inducers. Blood 1981;58:836-43.

10 Douer D, Koeffler HP. Retinoic acid enhances colonystimulating factor-induced clonal growth of normal human myeloid progenitors in vitro. Exp Cell Res 1982;138:193-8.

11 Douer D, Koeffler HP. Retinoic acid inhibition of the clonal growth of human myeloid leukaemia cells. J Clin Invest 1982;69:277-83.

12 Bailey-Wood R, May S, Jacobs A. The effect of retinoids on CFU-GM from normal subjects and patients with myelodysplastic syndrome. Br J Haematol 1985;59:15-20.

13 Gold EJ, Mertelsman RH, Itri LM, et al. Phase I clinical trial of 13-cis retinoic acid in myelodysplastic syndromes. Cancer Treat Rep 1983;67:981-6.

14 Besa EC, Hyzinski M, Nowell PC, Abrahm JL. High dose prolonged 13-cis retinoic acid (RA) is required for clinical response in myelodysplastic syndrome (MDS). Blood 1985;66 (suppl 1):194a.

15 Clark RE, Ismail SAD, Jacobs A, Payne H, Smith SA. A randomised trial of 13-cis retinoic acid and cytosine arabinoside in patients with the myelodysplastic syndrome. Br J Haematol 1987;66:77-84.

16 May SJ, Smith SA, Jacobs A, Williams A, Bailey-Wood R. The myelodysplastic syndrome: analysis of laboratory characteristics in relation to the FAB classification. Br J Haematol 1985;59:311-9.

17 Mannoni P, Janowska A, Fromont P, Weiblen B, Turner AR, Turc JM. Human myeloid differentiation studied by monoclonal antibodies. In: Bernard A, ed. Leucocyte typing. Berlin: Springer Verlag, 1984:410-9.

18 Zola H, McNamara P, Thomas M, Smart IJ, Bradley J. The preparation and properties of monoclonal antibodies against human granulocyte membrane antigens. $\mathrm{Br} \mathrm{J}$ Haematol 1981;48:481-90.

19 Janowska-Wieczorek A, Mannoni PJ, Krantz MJ, Turner AR, Turc JM. Inhibition of CFU-GM, BFU-E and CFU-GEMM colony formation by monoclonal antibodies selected from the myeloid panel. In: Reinherz EL, ed. Leucocyte typing II. Vol 3. Human myeloid and haemopoietic cells. Berlin: Springer Verlag, 1986:171-80.

20 Hogg N, Horton MA. Joint report of the myeloid section of the third international workshop on human leucocyte differentiation antigens. In: McMichael AJ, ed. Leucocyte Antigens III. Oxford: Oxford University Press, 1987: 576-602.

21 Bernard A, Bernstein I, Boumsell L, et al. Nomenclature for clusters of differentiation (CD) of antigens defined on human leucocyte populations. Bull WHO 1984;62:809-11.

22 Iscove NN, Sieber S, Winterhalter KH. Erythroid colony formation in culture of mouse and human bone marrow; an analysis of the requirements for erythropoietin by gel filtration and affinity chromatography in agarose-concanavalin A. $J$ Cell Physiol 1974;83:309-20.

23 Bailey-Wood R, Dallimore CM, Smith SA, Whittaker JA. Use of logistic regression analysis to improve prediction of prognosis in acute myeloid laukaemia. Leuk Res 1984;8:667-79.

24 Dixon WJ, Brown MB. BMDP-79 Biomedical computer programmes P-series, Berkeley: University of California Press, 1979.

25 McClean SW, Ruddel ME, Gross EG, De Giovanna JJ, Peck GL. Liquid-chromatographic assay for retinol analogs in therapeutic trials. Clin Chem 1982;28:693-6.

26 Hokland P, Kerndrup G, Griffin JD, Ellegaard J. Analysis of leucocyte differentiation antigens in blood and bone marrow from preleukaemia (refractory anaemia) patients using monoclonal antibodies. Blood 1986;67:898-902.

27 Harlan JM. Leucocyte-endothelial interactions. Blood 1985; 65:513-25.

28 Kobayashi K, Fukita K, Okino F, Kajii T. An abnormality of neutrophil adhesion: Autosomal recessive inheritance associated with missing neutrophil glycoproteins. Pediatrics 1984;73:606-10.

29 Bowen TJ, Ochs HD, Altman LC, et al. Severe recurrent bacteria infections associated with defective adherence and chemotaxis in two patients with neutrophils deficient in a cell-associated glycoprotein. J Pediatr 1982;101:932-40.

30 Babior BM. Oxidants from phagocytes: agents of defense and destruction. Blood 1985;64:959-65.

31 Weisdorf DJ, Oken MM, Johnson GJ, Rydell RE. Chronic myelodysplastic syndrome: short survival with or without evolution to acute leukaemia. Br J Haematol 1983;55:691-700.

32 Ferrero D, Pessano S, Pagliardi GL, Rovera G. Induction of differentiation of human myeloid leukaemias: surface changes probed with monoclonal antibodies. Blood 1983;61:171-9.

33 Felsted RL, Gupta SK, Glover CJ, Fischkoff SA, Gallagher RE Cell surface membrane protein changes during the differentiation of cultured human promyelocytic leukaemia HL-60 cells. Cancer Res 1983;43:2754-61.

34 Findley HW, Steuber CP, Ruymann FB, McKolanis JR, Williams DL, Ragab AH. Effect of retinoic acid on myeloid antigen expression and clonal growth of leukaemic cells from children with acute non lymphocytic leukaemia - a paediatric oncology group study. Leuk Res 1986;10:43-50.

35 Douer D, Koeffler HP. Retinoic acid enhances growth of human early erythroid progenitor cells in vitro. J Clin Inves 1982;69:1039-41.

36 Breitman TR, Collins SJ, Keene BR. Terminal differentiation of human promyelocytic leukaemia cells in primary culture in response to retinoic acid. Blood 1981;57:1000-4.

Requests for reprints to: Dr RE Clark, Department of Haematology, University of Wales College of Medicine, Heath Park, Cardiff CF4 4XN, Wales. 